\title{
Impact of Monetary Policy on Private Investment
}

\author{
Saleem *
}

\begin{abstract}
In this paper, the impact of real discount rate, government investment and foreign direct investment on private investment in Pakistan, both in short run and long run, has been investigated by using annual time series data over the period of 1975-2015. The research includes Augmented Dickey Fuller (ADF) unit root test, Johansen and Juuselieus?s co-integration technique, Auto Regressive Distributed Lag (ARDL) bound testing model, Error Correction Model (ECM) and Causality Analysis to support the various findings. Results of ECM and Cointegration analysis suggests that a significant negative short and long run relationship exists between private investment and real discounted rate of return. Whereas, causality analysis confirms the unidirectional causality exists between real discounted rate of return and private investment. It is therefore recommended that both, government and monetary institution of Pakistan has to be very clear and careful while formulation monetary policy, especially with reference to enhance the private investment in the country.
\end{abstract}

Keywords: Private Investment, Real Discounted Rate, Cointegration, ARDL and ECM.

\section{Introduction}

All the economies of present world have a multiple economic objectives such as stable inflation, high economic growth and creating employment opportunities for enhancing living standards of the individuals. For achieving all such objectives, a balanced monetary policy is required to be formulated by the monetary institution of the country.

Firstly the approach, the monetary policy is adopted and then transferred to the real economic worlds, has always provided a significant interest to all present day economists and policy makers. There have always been differences of opinion among the policymakers regarding the impact of monetary policy on investment. Money supply and rate of interest are the two important tools of monetary policy. Theoretically, a change in interest rate can bring a visible change in making investing decisions. If rate of interest rate rises then level of investment reduces in any economy. As in the developing countries like Pakistan, it has been quite interesting to look at the inconsistent variation of the different economic variables.

For instance; the rate of interest in the decade of seventies was at an average rate of $8 \%$. Further, in the second decade i.e. in eighties, the rate of interest rises by an average rate of $2 \%$. Similarly, in the nineties, the average rate further goes up by $4 \%$ and reaches at $14 \%$ and in the year 1997 only it reaches at highest point i.e. 19\%. Moreover, in the

\footnotetext{
*Ph.D. scholar,IQRA University, Karachi-75300, Pakistan.

E-mail: salimsir@hotmail.com
} 
last decade i.e. from 2001 to 2010, it decreases by an average rate of $3.8 \%$, and reaches at $10 \%$. Finally, in the last five years, the average discounted rate further falls and reaches at $9.32 \%$. Surprisingly, in the year 2015 it reaches at $6 \%$.

Similarly, the trend of private investment in Pakistan could historically be observed that in almost every year monetary value of private investment has increased but at in a highly different variation as compared to previous year (chain base method) except in a very few cases, the monetary value as compared to past year, has fallen down for instance; in 1998 and 2009.

In contemporary world of economy, credit and investment are assumed to be the base of the modern economy without which no economic development and growth could be imagined. The credit is taken the lifeblood that circulates in the veins of economy. Controlling the credit is one of the main functions to run an economy which is assigned to the central bank of the country. For achieving the goals and objectives of the monetary policy, the central bank of the country, through the commercial banks controls the credit creation because inflation and deflation are the main causes of economic instability.

Furthermore, there are very few studies have been conducted regarding the subject of this study in all over the world, particularly in Pakistan to identify and underline the interdependence exists between monetary policy and private investment. Hence this research is very important for theoretical and empirical aspects of all economic policy makers, especially with reference to Pakistan. Special attention has been assigned to monetary concerned authority to understand the forecast for the future development of the economy and also to develop understanding how the estimated outcome may possibly be affected to policy changes.

This study has defined and provided the significance of monetary policy for the economic development of developing countries, especially with reference to Pakistan. The monetary policy works as a back bone for all the government to achieve their prime objectives for the welfare of the people such as full employment, high economic growth, price stability, etc. This study also provides the requisite information to different decision makers, policy makers and parties, i.e. financial institutions, investors, banks, creditors, government officials, business institutions, etc.

- What is the long-run and the short-run relationship between private investment and monetary policy with respect to Pakistan?

Following the introduction, the rest of the paper is organized as follows. Section 2 represents the theoretical framework of classical group of thoughts and Keynes theory. Further it also discusses reviews of empirical literature on the same area. Modeling framework is discussed in Section 3. Section 4 describes the estimation and results of various tests conducted in this study while Section 5 concludes the study and provides directions for further research. 


\section{Literature Review}

There are number of well-established theories related to the monetary policy and private investment has been developed by different economist at different intervals of time. However, a mixed type of empirical results have been found during previous researches. In this section, some of the studies have been discussed.

\section{Theoretical Background}

According to the classical group of economists, change in interest rate impacts negatively to private sector particularly when public expenditure are financed by making changes in monetary policy. In fact, according to classical group, public intervention reduces the fund management capacity for the private sector, especially in the field of investment. This scenario according to the classical group of economists, which increases public borrowing and displacing investment in the private sector, was termed as crowding out effect . On the other hand crowding in concept explains that private investment rises as debt financed government expenditure rises. It is due to government demand increases for goods or services, private investors will be encouraged and private sector investment will also go high.

The Modern economists do not agree with the classical point of view. They believe that the govt. budget should be surplus to increase the aggregate demand, including level of private investment in the country. They also have an opinion that the public finance should be dynamic and not to be static. If the public budget goes deficit, the government imposes taxes to curtail the purchasing power of the people and to lower down the prices. Similarly, during deflation taxes are imposed on income so that the level of investment and consumption may be raised through effective demand. On the other hand during inflation taxes are levied on consumption to bring down the level of prices by decreasing demand (Mankiw, 2004).

\section{Empirical Studies}

We feel that a thorough literature reviews are required to support and confirm the relationship between our focused variables so that we can conclude whether the relationship between variables are supported or not.

According to previous studies, such as Atoyebi, Adekunjo, Kadiri, and Falana (2012) found the determinants of domestic private investment in Nigeria by using time series data from 1970 to 2010. They found that interest rate has significant negative relation with private investment and it further explains that GDP and credit to private sector are important determinants to private investment. Bibi, Khan, and Bibi (2012) estimated co-integration technique to determine long run relationship between investment and savings in Pakistan by data covering the period of 1980-2009. Research found that when trade is open capital, investment impacts negatively in an economy. 
Fatima et al. (2011) has investigated the association between fiscal deficit and private investment in Pakistan by applying time series data 1980-2009. By using simultaneous equation, she has tested unit root test, Dickey-Fuller and Augmented. Multiple variables like; GDP, export, import, fiscal deficit, real interest rate, inflation and investment were also used during research. Results show that the investment and export has positive relationship with GDP. Further, import and fiscal deficit has inverse relationship with GDP. Also inflation has adverse impact on GDP. She has recommended government to take remedies to reduce fiscal deficit by improving taxation system and also reduce interest rate to increase investment. Hassan and Salim (2011) investigated factors effecting private investment in Bangladesh by using time series data from 1974 to 2003. The results show that external debt and national output impacts positively to private investment whereas government expenditure and real interest rate affects negatively to private investment. The results also explains that the coefficients of real interest rate is not statistically significant.

Anastasia, Omade, and Osemen (2011) examines that how monetary policy makes impact on private investment in Nigeria. Regression Model was used to test and confirm relationship between independent and dependent variables. Their research shows that Private investment increases as money supply increases. They also have recommended to the govt. to increase money supply, to encourage private investment by adjusting certain variables. Mohiudin and Salam (2011) have estimated the determinants of foreign direct investment in Pakistan by using time series data from 1979 to 2008. Results of unit root test shows that all independent variables are cointegrated with FDI. Further results of estimation shows that price and FDI have inverse relationship. Institutions of policy makers have been recommended to make attempts for sound and reasonable law and order situation for attracting foreign investors.

Mitra (2006) examined whether investment of government crowded out private investment in India during the period from 1969 to 2005. The results of test explained that government investment has significant negative impact in the short run on private investment. Valadkhani (2004) analyzed the determinants of private investment, both in short and long run, by using time series data from 1960-2000 for short run model and 2000 and 2002 for long run respectively. For findings Johansen Cointegration Technique by applying private investment, inflation, non-oil GDP was used. The results in long run shows that inflation and investment have negative relationship, while in short run private investment is cointegrated with inflation and non-oil GDP. It was recommended that without making amendments in constitution and controlling inflation growth of private investment is very difficult. Serv'en (2003) investigated the volatility between private investment and real exchange rate in 61 developing countries. This study indicates a significant negative effects between private investment and real interest rate. It was further concluded that under strong financial development and low trade openness, volatility between private investment and real exchange rate may have positive impact.

As per this research, a mix type of results are obtained. We therefore cannot conclude that in Pakistan exactly what kind of relationship exists among the selected variables. It 
is therefore, advised that similar kind of studies are required for further evidences.

\section{Methodology}

After analyzing both theoretical and empirical tests, the model to investigate the impact of real discount rate, government investment and foreign direct investment on private investment has been described as follows:

$$
P I_{t}=\alpha_{0}+\beta_{1} R D R_{t}+\beta_{2} G I_{t}+\beta_{3} F D I_{t}+\epsilon_{t}
$$

Where PI represents Private investment which includes domestic fixed assets, gross outlays from the private sector and non-profit agencies, RDR shows the authorized real discount rate charged by central bank to commercial, depository banks for advances to minimize temporary shortages of funds, GI represents gross fixed investment by public sector only, FDI represents Foreign Direct Investment Flows and $(\alpha)$ is constant, $(\beta)$ for coefficients, et describes the error terms.

In this quantitative research a time series analysis have been employed by using secondary data from 1975-2015. The main sources of the data are World Bank and a handbook of statistics on Pakistan Economy.

\section{Unit Root Analysis}

Augmented Dickey Fuller (ADF) unit root tests is applied to examine the stationary properties for long-term connection of given time series data.

$$
\Delta Y_{t}=\alpha_{0}+\alpha_{1} Y_{t-1}+\sum_{j=1}^{k} d_{j} \Delta Y_{t-j}+\epsilon_{t}
$$

Where $\Delta$ is first difference operator, $\epsilon_{t}$ is a pure white noise error term, $\alpha_{0}$ is a constant number in the equation, $k$ is the maximum number of lag of criterion variable and $\mathrm{Y}_{t}$ is a series of time. Dickey and Fuller (1979) test is used to investigate whether the estimations are equivalent to zero or not. This test gives the collective distribution of Augmented Dickey Fuller statistics. The variable is called stationary, if the coefficient value $\alpha_{1}$ is less than the critical values from statistics table.

\section{Cointegration Analysis}

To study the long-run relationship between focused variables, we used the autoregressive distributed lag (ARDL) method of co-integration established by Pesaran and Shin (1998); Pesaran, Shin, and Smith (2000, 2001). ARDL approach has preference over other cointegration methods because ARDL can be used regardless of whether selected variables are stationary at I(0), I(1) or mutually co-integrated (Pesaran \& Shin, 1998). The ARDL method has better estimated for small sample properties (Haug, 2002; Shah, 2016; Sharif, Raza, et al., 2016). Regardless explanatory variable is endogenous even then in ARDL 
method, the estimations may be performed (Pesaran \& Shin, 1998; Pesaran et al., 2001, 2001).

The null hypothesis of no cointegration is rejected if the calculated F-test statistics exceeds the upper critical bound (UCB) value. The results are said to be inconclusive if the F-test statistics fall between the upper and lower critical bound. Lastly, the null hypothesis of no cointegration is accepted if the F-statistics is below the lower critical bound (Nathan, Liew, \& Wong, 2016; Arif \& Suleman, 2017).

$$
P I_{t}=\zeta_{0}+\zeta_{1} \sum_{i=1}^{p} R D R_{t-1}+\zeta_{2} \sum_{i=1}^{p} G I_{t-1}+\zeta_{3} \sum_{i=1}^{p} F D i_{t-1}+\mu_{t}
$$

\section{Error Correction Model}

After confirmation of long-run relationship, ECM (Error Correction Model) is used to estimate the short run relationship among selected variables, according to given results of ECM, error correction term has significant probability with negative coefficient which is the confirmation of short run relationship among selected variables.

$$
\Delta P I_{t}=\varphi_{0}+\varphi_{1} \sum_{i=1}^{p} \Delta R D R_{t-1}+\varphi_{2} \sum_{i=1}^{p} \Delta G I_{t-1}+\varphi_{3} \sum_{i=1}^{p} \Delta F D I_{t-1}+n E C T_{t-1}+\mu_{t}
$$

\section{Results and Estimation}

The fundamental purpose of this study is to examine the impact of monetary policy on private investment in long run and short run as well, in Pakistan. The main sources of variable data have been collected from world data bank and handbook of statistics on Pakistan Economy. Ordinary Least Square Technique has been used in Regression Analysis to find out the impact of monetary policy on private investment in Pakistan. For stationary analysis and long run relationship between the observed variables, ADF unit root technique has been used. For further confirmation, ARDL Bound Test has also been applied. To estimate short run relationship ECM technique has been used and to find out cause and effect Granger Causality has also been used.

\section{Stationary Analysis}

Before employing Regression Analysis a Stationary Analysis have been used to test the trend and behavior of all variables. In this regard a Unit Root Test - Augmented Dickey Fuller conducted. Results of the study are shown in Table 1 (Jawaid \& Saleem, 2017). 
Table 1

Stationary Test Results

\begin{tabular}{ccccccccc}
\hline Variables & \multicolumn{4}{c}{$\mathbf{1}(\mathbf{0})$} & \multicolumn{4}{c}{$\mathbf{1}(\mathbf{1})$} \\
\hline & C & Prob. & C\&T & Prob. & C & Prob. & C\&T & Prob. \\
PI & 5.612 & 1.000 & 1.451 & 1.000 & -2.851 & 0.060 & -4.309 & 0.007 \\
RDR & -2.051 & 0.264 & -1.877 & 0.647 & -4.312 & 0.001 & -4.399 & 0.006 \\
GI & 4.512 & 1.000 & -4.866 & 0.001 & -3.21 & 0.026 & -4.861 & 0.001 \\
FDI & -2.454 & 0.133 & -3.112 & 0.118 & -3.981 & 0.003 & -3.902 & 0.021 \\
\hline
\end{tabular}

Source: Author's estimations

The results of Table 1, indicates that all variables are non-stationary and insignificant at level i.e. 1(0) except GI which shows significant and stationary with C\&T at level. It has also been assumed a null hypothesis for all non-stationary results and alternative hypothesis for all stationary results in the data. Considering the above results it has been found that all variables are stationary at first difference i.e. 1(1). Hence null hypotheses on unit root test will be rejected at 1(1). Since the results are stationary from the given data, this indicates series may exist a long run relationship.

\section{Long Run Relationship Analysis}

\section{Cointegration}

Further to test the long run relationship among the variables, a Johansen Juselieus (1990) co-integration test has been conducted. Hence the two test statistics have been used for cointegration, are Trace statistics and Maximum Eigen statistics. Table 2 explains the calculated and critical values of these two statistics. A null hypothesis have been assumed i.e. there is no cointegration among the selected variables (Jawaid, Abbas, \& Saleem, 2017). To explore out the long run relationship between considered variables Johansen and Juselius (1990) cointegration test has been used. Trace statistics and Max. Eigen Statistics have been applied to predict cointegration. Table:2 explained the calculated values of these two tests. Test hypothesis is there is no cointegration between the selected variables is rejected by the estimated values and the long run relationship is found among our model variables at a significance level of $5 \%$.

Table 2

Cointegration test results

\begin{tabular}{ccccccc}
\hline Null Hypothesis & Trace & 5\% critical values & Prob. & Max. Eigen Value & $\mathbf{5 \%}$ critical values & Prob. \\
\hline None $*$ & 136.041 & 63.876 & 0.000 & 67.701 & 32.118 & 0.000 \\
At most 1 & 68.339 & 42.915 & 0.000 & 45.314 & 25.823 & 0.000 \\
At most 2 & 23.025 & 25.872 & 0.108 & 19.03 & 19.387 & 0.056 \\
At most 3 & 3.994 & 12.517 & 0.742 & 3.994 & 12.517 & 0.742 \\
\hline
\end{tabular}

Source: Author's estimations

The results of Table 2 illustrates the rejection of null hypothesis for both these test statistics i.e. trace statistics and Maximum Eigen value statistics. Therefore, on the basis 
of the above results, it is concluded that the long-run relationship exists among the selected variables.

Table 3

Bound Testing

\begin{tabular}{ccc}
\hline \multicolumn{1}{c}{ Test Statistic } & Value & K \\
\hline F-statistic & 23.566 & 3 \\
\hline \multicolumn{2}{c}{ Critical Value Bounds } & \\
\hline Significance & I0 Bound & I1 Bound \\
\hline $10 \%$ & 2.72 & 3.77 \\
$5 \%$ & 3.23 & 4.35 \\
$3 \%$ & 3.69 & 4.89 \\
$1 \%$ & 4.29 & 5.61 \\
\hline
\end{tabular}

Source: Author's estimations

To estimate the long run relationship among private investment, discounted rate of return, govt. investment and foreign direct investment, Autoregressive Distributed Lag Method have been used. Table 3 shows the results of ARDL cointegration test see also (Jawaid, 2014; Jawaid \& Raza, 2013).

The results of ARDL test explains that there is significant long run relationship exists among the variables. We therefore reject the null hypothesis that there is no cointegration in model since the value of F-statistics is greater than the upper bound at various level of significance.

Table 4

ARDL

\begin{tabular}{lcccc}
\hline Variable & Coefficient & Std. Error & t-Statistic & Prob.* \\
\hline PI(-1) & -0.374 & 0.136 & -2.748 & 0.012 \\
PI(-2) & 0.157 & 0.137 & 1.140 & 0.268 \\
PI(-3) & 0.502 & 0.128 & 3.920 & 0.001 \\
PI(-4) & 0.904 & 0.171 & 5.270 & 0.000 \\
GI & 0.984 & 0.166 & 5.917 & 0.000 \\
GI(-1) & -0.967 & 0.291 & -3.319 & 0.003 \\
GI(-2) & 2.184 & 0.331 & 6.599 & 0.000 \\
GI(-3) & -1.603 & 0.231 & -6.937 & 0.000 \\
FDI & 3.134 & 0.179 & 17.524 & 0.000 \\
FDI(-1) & -2.377 & 0.449 & -5.290 & 0.000 \\
FDI(-2) & 1.937 & 0.434 & 4.463 & 0.000 \\
FDI(-3) & -2.540 & 0.379 & -6.710 & 0.000 \\
RDR & -10338.360 & 3442.391 & -3.003 & 0.007 \\
RDR(-1) & 2312.428 & 3843.705 & 0.602 & 0.554 \\
RDR(-2) & -10543.840 & 3907.613 & -2.698 & 0.014 \\
RDR(-3) & 15900.160 & 3078.740 & 5.165 & 0.000 \\
C & 11239.160 & 28182.920 & 0.399 & 0.694 \\
\hline Adjusted $R_{2}$ & \multicolumn{5}{c}{0.999} \\
F-statistic(Prob) & $4382.511(0.000)$ & & \\
Durbin-Watson stat & \multicolumn{5}{c}{. } & \\
\hline Source: Author's estimations
\end{tabular}

Similarly results of Table 4 explains that there is significant negative long run relationship exists between private investment and discounted rate of return. These findings of 
negative relationship between private investment and discounted rate of return are matched with economic principles explained by classical group of thoughts and termed as crowding out effect. They believe that with fall in RDR, investors will be highly encouraged to borrow from commercial institutions which results rising level of PI in an economy. Whereas, the results of Table 4 shows that government investment and foreign direct investment has significant positive long run relationship with private investment. These findings of positive relationship between private investment and government investment are highly recognized by modern economists. They have of the opinion that with increase in GI, aggregate demand will also increase hence private investor will be encouraged to raise investment to increase level of production at macro level.

\section{Short Run Relationship}

For estimation of short-run relationship among the selected variables, Error Correction Model (ECM) has been used. The results in table 5 of ECM shows the value of ECT is negative and significant. We therefore conclude that the model is covering quickly to the equilibrium value see also (Tehseen Jawaid \& Raza, 2012; Abdul \& Jawaid, 2010).

\begin{tabular}{lccr}
$\begin{array}{l}\text { Table 5 } \\
\text { ECM }\end{array}$ & Coefficient & t-Statistics & Prob. \\
\hline Variable & 18688.620 & 1.327 & 0.193 \\
\hline $\mathrm{C}$ & 0.272 & 1.453 & 0.155 \\
$\mathrm{D}(\mathrm{PI}(-1))$ & 1.120 & 2.654 & 0.012 \\
$\mathrm{D}(\mathrm{GI})$ & 1.104 & 3.318 & 0.002 \\
$\mathrm{D}(\mathrm{FDI})$ & -12353.040 & -1.453 & 0.155 \\
$\mathrm{D}(\mathrm{RDR})$ & -0.459 & -2.031 & 0.050 \\
$\mathrm{ECT}(-1)$ & & 0.517 & \\
\hline Adjusted R-squared & & 1.779 & \\
Durbin-Watson stat & & 9.133 & \\
F-statistic(Prob) & & &
\end{tabular}

\section{Causality analysis}

The direction of causality analysis have been performed between discounted rate of return and private investment by employing Granger Causality Test (1969). The current model of Granger shows causality analysis at Lag 1 . Results of causality test have been displayed in Table 6. Lag 1 actually shows the significant unidirectional causality occurs through last year's discounted rate of return to private investment for the next year see also (Jawaid, Haq, et al., 2012; Jawaid, Raza, Mustafa, \& Karim, 2016).

Table 6

Granger Causality

\begin{tabular}{lccc}
\hline Variables & Lag & F-Statistics & Prob. \\
\hline RDR does not Granger Cause PI & 1 & 9.389 & 0.004 \\
PI does not Granger Cause RDR & & 1.103 & 0.302 \\
\hline
\end{tabular}

Source: Author's estimations 


\section{Conclusion and Recommendations}

\section{Conclusion}

The purpose of the study is to find out the impact of monetary policy on private investment in Pakistan by using data from the period of 1975-2015. In the contemporary world of economy, investment is believed to be the key source of economic uplifting without which neither an economic development nor growth can be achieved. Therefore, in this research, the main focus is to determine how monetary policy effects on private investment in Pakistan. Results of error correction model and cointegration analysis proposes that a significant negative short and long run relationship exists between private investment and discounted rate of return in Pakistan. These findings are actually in favor of several developed economic theories which explains that with low rate of interest imposed by central bank, investors are encouraged to borrow money from financial institutions, which finally becomes a cause of rising level of private investment in an economy. Further Augmented Dickey Fuller Test also confirms that discounted rate of return, government investment and foreign direct investment are good to predict private investment in Pakistan. Causality analysis shows that unidirectional causality moves from discounted rate of return to private investment i.e. with the help of real discount rate of last year, private investment for the current year can significantly be predicted.

\section{Recommendations}

This research has a lot of implications for policy in the country. The key one is monetary policy' which is extremely necessary to be improved in order to attract private investment in Pakistan. In addition, this study has also indicated that the effect of aggregate monetary policy is highly significant for the flow of private investment sector in the country.

Knowing the fact in this regard, there is an extreme need to look closely into the monetary and fiscal policies to improve the overall economic performance. Moreover, for improving the effectiveness of the monetary policy following necessary adjustments should be recommended to encourage private investment in Pakistan.

- It is suggested to the monetary institution of Pakistan to be very clear, and careful while formulating monetary policy especially with reference to enhance the private investment in Pakistan. For instance; the policy maker of the monetary institutions should determine a very balance real discount rate, neither very high nor low. If a very high rate of interest is decided for the monetary policy than saving in the country will raise and hence private investment will also increase but investors will find discouragement to pay high rate of interest. Similarly, low rate of interest encourage to the investors to receive high credit but will discourage the saving and private investment in the country.

- It is a prime need especially with reference to Pakistan to establish stable political environment because instable political environment, in short and long run, can negatively impacts on private investment. 
- Commercial banks are also advised to establish acceptable monitoring channels to find out whether the corporations or firms are utilizing the advances properly or not.

\section{Future Recommendations}

The recommendation can be made in many different conducts for further improvement for future researchers, students, and policymakers.

- It is recommended for the future that, researchers should also find out the various other factors which can affect private investment in Pakistan, most commonly money supply, bank credit, saving function, inflation, GDP etc.

- It is also recommended that the effect of monetary policy should also be divided on city and provinces bases so that the contribution of each city and provinces can also be observed which will also help in future decision making.

- In Pakistan, poor law and order condition is also a matter of great concern. Govt. is advised to establish solid institutions to look into the matter seriously. 


\section{References}

Abdul, W., \& Jawaid, S. T. (2010). Inward foreign direct investment and aggregate imports: Time series evidence from Pakistan (Tech. Rep.). University Library of Munich, Germany.

Anastasia, O. C., Omade, S. I., \& Osemen, E. J. (2011). Long run relationship between private investment and monetary policy in Nigeria. , 1(10), 45-55.

Arif, I., \& Suleman, T. (2017). Terrorism and stock market linkages: An empirical study from a front-line state. Global Business Review, 18(2), 1-14.

Atoyebi, K., Adekunjo, F., Kadiri, K., \& Falana, A. (2012). The determinants of domestic private investment in Nigeria. Journal of Humanities and Social Science, 2(6), 4654.

Bibi, S., Khan, U. A., \& Bibi, A. (2012). Determinants of investment in Pakistan. Academic Research International, $2(2), 517$.

Dickey, D. A., \& Fuller, W. A. (1979). Distribution of the estimators for autoregressive time series with a unit root. Journal of the American Statistical Association, $74(366 \mathrm{a})$, 427-431.

Fatima, G., Namazi, M., Forougozar, H., Namazi, N. R., Ting, C.-J., Arjchariyaartong, W., ... Zadeh, A. E. (2011). Testing relationship of private investment and GDP with fiscal deficit. In International conference on financial management and economics ipedr (Vol. 11, pp. 367-372).

Hassan, A. K., \& Salim, R. A. (2011). Determinants of private investment: Time series evidence from Bangladesh. The Journal of Developing Areas, 45(1), 229-249.

Haug, A. A. (2002). Temporal aggregation and the power of cointegration tests: A Monte Carlo study. Oxford Bulletin of Economics and Statistics, 64(4), 399-412.

Jawaid, S. T. (2014). Trade openness and economic growth: A lesson from Pakistan. Foreign Trade Review, 49(2), 193-212.

Jawaid, S. T., Abbas, S., \& Saleem, S. M. (2017). Democracy and international financial integration in Pakistan. Indian Growth and Development Review, 10(1).

Jawaid, S. T., Haq, A. U., et al. (2012). Effects of interest rate, exchange rate and their volatilities on stock prices: Evidence from banking industry of Pakistan. Theoretical and Applied Economics, 8(8), 153.

Jawaid, S. T., \& Raza, S. A. (2013). Effects of terms of trade on growth performance of India. Economic Modelling, 33, 940-946.

Jawaid, S. T., Raza, S. A., Mustafa, K., \& Karim, M. Z. A. (2016). Does inward foreign direct investment lead export performance in Pakistan? Global Business Review, $17(6), 1296-1313$.

Jawaid, S. T., \& Saleem, S. M. (2017). Foreign capital inflows and economic growth of Pakistan. Journal of Transnational Management, 22(2), 121-149.

Mankiw, N. G. (2004). Principles of macroeconomics. Thomson/South-Western, Mason, $\mathrm{OH}$.

Mitra, P. (2006). Has government investment crowded out private investment in India? The American Economic Review, 96(2), 337-341. 
Mohiudin, S., \& Salam, M. A. (2011). Determinants of foreign direct investment in Pakistan. Journal of Independent Studies.

Nathan, T. M., Liew, V., \& Wong, W.-K. (2016). Disaggregated energy consumption and sectoral outputs in Thailand: ARDL bound testing approach. Journal of Management Sciences, 3(1), 34-46.

Pesaran, M. H., \& Shin, Y. (1998). An autoregressive distributed-lag modelling approach to cointegration analysis. Econometric Society Monographs, 31, 371-413.

Pesaran, M. H., Shin, Y., \& Smith, R. J. (2000). Structural analysis of vector error correction models with exogenous I(1) variables. Journal of Econometrics, $97(2)$, 293-343.

Pesaran, M. H., Shin, Y., \& Smith, R. J. (2001). Bounds testing approaches to the analysis of level relationships. Journal of Applied Econometrics, 16(3), 289-326.

Serv'en, L. (2003). Real-exchange-rate uncertainty and private investment in LDCs. Review of Economics and Statistics, 85(1), 212-218.

Shah, N. (2016). The impact of working capital management on firms profitability in different business cycles: Evidence from Pakistan. Journal of Finance 63 Economics Research, 1(1), 58-70.

Sharif, A., Raza, S. A., et al. (2016). Dynamic relationship between urbanization, energy consumption and environmental degradation in Pakistan: Evidence from structure break testing. Journal of Management Sciences, 3(1), 1-21.

Tehseen Jawaid, S., \& Raza, S. A. (2012). Workers' remittances and economic growth in China and Korea: An empirical analysis. Journal of Chinese Economic and Foreign Trade Studies, 5(3), 185-193.

Valadkhani, A. (2004). What determines private investment in Iran? International Journal of Social Economics, 31(5/6), 457-468. 